\title{
A Note On The Effect Of M\&A
} Announcements On Stock Price Behavior \section{And Financial Performance Changes: The Case Of Arab Malaysian Bank Berhad And Hong Leong Bank Berhad}

\author{
Carl B. McGowan, Jr., Norfolk State University, USA
}

Zunaidah Sulong, Universiti Putra, Malaysia

\begin{abstract}
This study examines the effect of $M \& A$ completion announcements on the stock price behavior for two anchor banks in Malaysia: Hong Leong Bank Berhad and Arab Malaysian Bank Berhad. The analysis uses the event study technique, the Nä̈ve Model, a model that is based on Market Model with constrained $\alpha=0$ and $\beta=1$ to compute the abnormal returns surrounding the $M \& A$ completion announcement date and to evaluate the effect of $M \& A$ completion announcement on the banks' return. The results from event study show that the $M \& A$ completion announcements are treated as positive information by the market.
\end{abstract}

Keywords: Mergers and acquisitions; Event study; Malaysian; Financial performance

\section{INTRODUCTION}

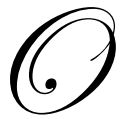

ne explanation of the Asian Financial Crisis of 1997-1998 is that the financial crisis resulted from the Contagion Effect after the Thai Baht collapse. Siegel (2002) states that leaving a fixed currency regime for a developing economy implies significant other problems, all of which were present in Thailand. These problems would include balance of payments deficits, government spending deficits, and increasing inflation. Investors leaving the Baht also left other Asian currencies leading to currency collapse in the region. Siegel (2002) further states that investors assumed that if Thailand was having fundamental economic problems, the other Asian countries might be having similar problems. Unlike the rest of the Asian countries affected by the Financial Crisis, Malaysia did not implement an IMF program but used a number of policy changes to control the effects of the Financial Crisis. Malaysia pegged the ringgit to the dollar and imposed selected capital controls to stabilize the currency (ringgit) and stop the capital outflow which was beyond the capability of the government to control.

One of the early programs of the Malaysian government to resolve the effects of the Financial Crisis was restructuring the financial system of Malaysia ${ }^{1}$. Danaharta ${ }^{2}$ was created in May 1998 to acquire and workout to the extent possible non-performing loans of Malaysian banks. Danamodal ${ }^{3}$ was created to restructure Malaysian banks whose equity had fallen below nine percent. The Corporate Debt Restructuring Committee was created to facilitate voluntary restructuring of corporate debt. In July 1998, the government announced a restructuring program to

\footnotetext{
${ }^{1}$ This paragraph is a summary based on Kawai (2000, pages 148-149).

${ }^{2}$ Pengurusan Danaharta Nasional Berhad - National Asset Management Company

${ }^{3}$ Danamodal Nasional Berhad is a corporation created to recapitalize Malaysian banks.
} 
consolidate fifty-eight financial institutions in Malaysia into six major bank groups ${ }^{4}$. The anchor bank system was to consolidate the financial system to improve competitiveness and to reduce the number of bankruptcies in the financial system.

Mergers and acquisitions (M\&A) have been, a priori, associated with the strengthening of a firm's financial position and increasing firm value. Firms involved in a consolidation program should benefit operationally and financially as a result of M\&A activity. According to Ogden, Jen, and O'Connor (2003), the motives for M\&A include: (1) operating synergy; (2) financial synergy and diversification; (3) bankruptcy avoidance; (4) financial slack; (5) hubris; and (6) self-interest of the bidder's management.

Researchers have studied the effects of M\&A on the value of both the acquiring firm and the bidder firm. The evidence on mergers indicates that the stockholders of target firms have earned significant abnormal/excess return $^{5}$ not only around the announcement period, but also in the weeks after the announcement. Jensen \& Ruback (1983) review 13 studies that examine returns around takeover announcements and report an average abnormal return of 30\% to target stockholders in successful tender offers and $20 \%$ to target stockholders in successful mergers. Jarrell, Brickley, and Netter (1988) review the results of 663 tender offers made between 1962 to 1985, and note that premiums averaged 19\% in the 1960s, 35\% in the 1970s, and 30\% between 1980 and 1985. Other studies report an increase in the stock price of the target firms prior to the M\&A announcement, suggesting either a very perceptive financial market or leaked information about prospective deals.

Nevertheless, evidence on the effect of M\&A announcements on bidder firm stock prices is not clear cut and, in fact, is contradictory as empirical studies have shown mixed results. Desai and Stover (1985), James and Weir (1987), and Cornett and De (1991), among others, report positive abnormal returns to bidding firms in banking acquisitions. However, Neely (1987) and Cornett and Tehranian (1992) report negative returns to the bidder. Houston and Ryngaert (1994) suggest that samples which emphasize larger acquisitions are more apt to find negative bidder returns.

The purpose of this study is to examine the effect of M\&A completion announcements on the stock price behavior for two anchor banks in Malaysia: Hong Leong Bank Berhad and Arab Malaysian Bank Berhad. This study analyzes the impact of the M\&A on the operating performance of these two banks. This study covers the period from 1998 to 2003 and uses event study methodology.

This paper is organized as follows: section II presents the literature review on M\&A effect. Section III presents the data and methodology use in this paper. Section IV provides empirical results and discussions. Finally, a summary of main findings and implication as well as recommendation for further studies are presented in section V.

\section{LITERATURE REVIEW}

Fauzias (1992) in testing the efficiency of the Malaysian stock market's reaction to acquisition announcements uses the daily common stock returns of Kuala Lumpur Stock Exchange (KLSE) for a period ranging 200 days before and 200 days after the acquisition announcement date. Fauzias suggests that the bidder may have overestimated the value of the shares, which results in paying too much for the assets. The increase in share prices prior to the announcement may be due to information leakage, which causes prices to move up before the announcement is made.

Fauzias (1993) examines the effects of acquisition announcement on the price behavior of Malaysian bidders and target firms by using three alternative models: (1) a one factor market model; (2) the Capital Asset Pricing Model (CAPM); and (3) the regression estimation of $\alpha=0$ and $\beta=1$ in the model. The results show that the

\footnotetext{
${ }^{4}$ The six banking groups were later increased to ten banking groups: Maybank, Bumiputra Commerce, RHB Bank, AMMB, Hon Leong Bank, Multi-Purpose Bank, Southern Bank, EON Bank, and Public Bank.

${ }^{5}$ Abnormal/excess returns represent over and above the return that would have expected in an investment, after adjusting for risk and market performance.
} 
target's returns are negative but not statistically significant and the bidder's returns are negative and statistically significant after the announcement date.

Fauzias and Ruzita (2003) show that the market reaction to three announcements of corporate restructurings by the Malaysian Resources Corporation were statistically significant in terms of market reaction to each announcement. Fauzias and Ruzita's test results indicate that the market reacted to the initial restructuring announcement, increased in reaction to the second restructuring announcement, and produced mixed results to the third restructuring announcement.

Houston, James, and Ryngaert (2001) examine the factors that explain merger gains in 64 large banks and find that the bulk of the gains are from cost reductions particularly through reduction in geographical overlap. Rhoades (1998) investigates the efficiency effect of bank mergers by using case studies of nine mergers in America. He employs the same basic analytical framework in all of the case studies, such as financial ratios, econometric cost measures, and the effect of the merger announcement on the stock of the acquiring and acquired firms. All nine of the mergers resulted in significant cost cutting in line with pre-mergers projections. Four of the nine mergers were clearly successful in improving cost efficiency but five were not. The most frequent and serious synergies experienced in bank mergers that increase bidder returns relative to non-financial mergers was unexpected difficulty in integrating data processing systems and operations. ${ }^{6}$

\section{DATA AND METHODOLOGY}

This study uses 61 daily closing prices of the anchor banks and the daily closing price index of the Kuala Lumpur Stock Exchange Composite Index (KLCI) surrounding the M\&A completion announcement. Data on prices is collected from Thomson Datastream. The event dates are defined as the dates of announcement on the M\&A completions, namely 30 October 2000 and 20 December 2001 for Hong Leong Bank Berhad and Arab Malaysian Bank Berhad, respectively. The KLCI data is used to proxy the market return $\left(\mathrm{R}_{\mathrm{M}}\right)$. These data are to be used to examine the market reaction to the events based on the abnormal performance of the individual bank's stock surrounding the announcement.

Following Fauzias and Rasidah (2003), the Market Model with constrained $\alpha=0$ and $\beta=1$ is used to measure the abnormal performance. According to this model, the abnormal return (AR) for the individual bank for each day $t$ is,

$$
A R_{t}=R_{t}-R_{M, t}
$$

The cumulative abnormal returns (CAR) are the sum of the abnormal returns, that is,

$$
C A R_{s}=\sum_{t=K}^{L} A R_{t}
$$

where $\mathrm{K}$ to $\mathrm{L}$ are the days surrounding the announcement which in this study will be set at 30 days prior to until 30 days after the announcement.

To test the significance of the AR and CAR values, the methodology again follows Fauzias (2003) in calculating the $\mathrm{t}$-value of the two measures. The $\mathrm{t}$-value of the abnormal return is equal to,

$$
t=\frac{A R_{t}}{\sigma_{A R, t}}
$$

\footnotetext{
${ }^{6}$ Results of the analysis of performance measures for the two test banks indicate that there were no statistically significant performance improvements.
} 
where $\sigma_{A R, t}=\left[1 / N-1 \sum_{t=K}^{L}\left(A R_{t}-\bar{A} \bar{R}\right)^{2}\right]^{1 / 2}$ with AR(bar) is the average of the ARs over the period (N =

number of days from $\mathrm{t}=\mathrm{K}$ until $\mathrm{t}=\mathrm{L}$ ). Whereas, the $\mathrm{t}$-value for the CAR statistics is given as,

$$
t=\frac{C A R}{\sigma_{C A R}}
$$

where $\sigma_{\mathrm{CAR}}=\sigma_{\mathrm{AR}} \sqrt{\mathrm{N}}$ where $\mathrm{N}$ is the number of days in the CAR statistics.

In all cases, the null hypotheses that the M\&A completion announcement does not have any significant influence of the bank's stock return (i.e., $\mathrm{H}_{0}$ : $\mathrm{AR}=0$ and $\mathrm{CAR}=0$ ) are to be tested at 5 percent significant level. If the AR or CAR is statistically significant, then, the M\&A announcement is seen to have an effect on the market returns.

\section{EMPIRICAL RESULTS AND DISCUSSIONS}

Table 1 and Table 2 present the summary of the significant test results of both the Abnormal Returns (AR) and Cumulative Abnormal Returns (CAR) for the $(-30,+30)$ event windows. Individually, the percentage of statistically significant positive AR of Hong Leong's M\&A is forty-six percent and fifty-five percent (four of seven) of the statistically significant AR occur in the pre-announcement period. Table 2 shows that for Arab Malaysian Bank, forty-six percent of the AR are positive and seventy-five percent (three of four) of the statistically significant AR occur prior to the announcement date. The event window shows that neither of the M\&A announcements produce significant CAR regardless of the event period used. However, the total pre-announcement period CAR for Hong Leong Bank is $11.33 \%$ and for Arab Malaysian Bank is $2.37 \%$. For both banks, the stock value increased prior to the announcement of the completion of the M\&A.

Overall, the results are supportive of the argument that M\&A activity in the banking industry provides positive effects in these two cases based on the perception of the market. This evidence provides justification for the central bank's consolidation program for the domestic banking sector to improve the financial strength of the remaining banks. These results are consistent with the results found by Houston, Ryngaert, and Netter (2001) for the combined bidders and targets and for M\&A in the 1990s sub-sample.

\section{CONCLUSIONS, IMPLICATIONS AND, FUTURE RESEARCH}

Based on the results of the two individual anchor banks, due to the announcement of the completion of the M\&A exercise, the overall empirical results indicate that the M\&A completion announcements are treated as positive information. Even though in the case of the Arab Malaysian, the results are less strong. This evidence suggests that there might be a leakage or anticipation of information or that the market could easily anticipate the information of the completion of a progressing M\&A.

The overall results of this analysis provide empirical evidence to support the hypothesis that M\&A in the banking industry has a positive impact based on the perception of the market. The empirical results of this study provide justification to the Central Bank of Malaysia for the consolidation program of the domestic banking sector with the goal of improving the financial strength of remaining individual banks in Malaysia. These empirical results are consistent with the results found by Houston, Ryngaert, and Netter (2001) for the combined bidders and targets of M\&A in the 1990s sub-sample. 
Table 1

Summary of the significant test results on the anchor bank's AR and CAR due to the announcement on the completion of the merger and acquisition exercise of Hong Leong Bank Berhad on 30 October 2000

\begin{tabular}{|c|c|c|c|c|c|}
\hline \multicolumn{6}{|c|}{ Event Window of $(-30,+30)$} \\
\hline \multicolumn{3}{|c|}{ Abnormal Returns } & \multicolumn{3}{|c|}{ Cumulative Abnormal Returns } \\
\hline \multicolumn{3}{|c|}{$(-30,+30), \sigma_{\mathrm{AR}}=0.0218$} & \multicolumn{3}{|c|}{$(-30,+30), \sigma_{\mathrm{CAR}}=0.0218 \sqrt{61}$} \\
\hline Day & AR values & Sig t & Day & CAR & Sig t \\
\hline-20 & -0.0487 & -2.2304 & None & & \\
\hline-18 & 0.0595 & 2.7259 & & & \\
\hline-15 & 0.0421 & 1.9294 & & & \\
\hline-8 & 0.0440 & 2.0138 & & & \\
\hline 1 & -0.0506 & -2.3167 & & & \\
\hline 24 & 0.0493 & 2.2579 & & & \\
\hline 25 & -0.0450 & -2.0585 & & & \\
\hline
\end{tabular}

Note: For the $(-30,+30)$ event window, the AR and CAR values are significantly different from zero at $\alpha \leq 5$ percent and $\alpha \leq 1$ percent when t-stats $\geq 1.671$ and t-stats $\geq 2.390$, respectively.

Table 2

Summary of the significant test results on the anchor bank's AR and CAR from narrower event window due to the announcement on the completion of the merger and acquisition exercise of Arab Malaysian Bank Berhad on 20 December 2001

\begin{tabular}{|c|c|c|c|c|c|}
\hline \multicolumn{6}{|c|}{ Panel A: Event Window of $(-30,+30)$} \\
\hline \multicolumn{3}{|c|}{ Abnormal Returns } & \multicolumn{3}{|c|}{ Cumulative Abnormal Returns } \\
\hline \multicolumn{3}{|c|}{$(-30,+30), \sigma_{\mathrm{AR}}=0.0273$} & \multicolumn{3}{|c|}{$(-30,+30), \sigma_{\mathrm{CAR}}=0.0273 \sqrt{61}$} \\
\hline Day & AR values & Sig t & Day & CAR & Sig t \\
\hline-30 & 0.0465 & 1.7042 & None & & \\
\hline-28 & 0.1299 & 4.7629 & & & \\
\hline-5 & -0.0495 & -1.8133 & & & \\
\hline 26 & 0.0775 & 2.8404 & & & \\
\hline
\end{tabular}

Note: For the $(-30,+30)$ event window, the AR and CAR values are significantly different from zero at $\alpha \leq 5$ percent and $\alpha \leq 1$ percent when t-stats $\geq 1.671$ and $t$-stats $\geq 2.390$, respectively.

\section{AUTHOR INFORMATION}

Carl B. McGowan, Jr., PhD, CFA is a Professor of Finance at the School of Business at Norfolk State University. Dr. McGowan received a BA in International Relations and an ROTC commission from Syracuse University, an MBA (Finance) from Eastern Michigan University, and a PhD in Business Administration (Finance) from Michigan State University. From 2003 to 2004, he was the RHB Bank Distinguished Chair in Finance at the Universiti Kebangsaan Malaysia. He has taught in Cost Rica, Malaysia, Moscow, Saudi Arabia, and The UAE. His special area of interest is international risk analysis and foreign direct investment analysis analyzing the interaction between political and economic risk and FDI. Professor McGowan has published over one hundred papers and presented over one hundred and forty papers at conferences. Professor McGowan published in numerous journals including Applied Financial Economics, Decision Science, Financial Practice and Education, The Financial Review, The Journal of Applied Business Research, The Journal of Diversity Management, The Journal of Global Business, The Journal of Real Estate Research, Managerial Finance, The Southwestern Economic Review, and Urban Studies.

Zunaidah Sulong is a Doctoral student at the Graduate School of Business, Universiti Kebangsaan Malaysia, Malaysia and has been waiting her viva-voce on dissertation entitled "“'Dividends, ownership structure, board governance and firm value: A study of firms listed on the main board of Bursa Malaysia”. In 2000, Zunaidah received her MBA from Universiti Kebangsaan Malaysia. Since 2005, Zunaidah has been a full-time lecturing at the Faculty of Economics and Management, Universiti Putra Malaysia, Malaysia, teaching Finance subjects. 


\section{REFERENCES}

1. Cornett, M.M. and De, S. (1991). Common stock returns to corporate takeover bids: evidence from interstate bank merger. Journal of Banking and Finance: 273 - 296.

2. Cornett, M.M. and Tehranian, H. (1992). Changes in corporate performance associated with bank acquisitions. Journal of Financial Economics 31: 211 - 234.

3. Desai, A. and Stover, R. (1985). Bank holding company acquisitions, stockholder returns and regulatory uncertainty. Journal of Financial Research 8: $145-156$.

4. Fauzias, M.N. and Rashidah, M.S. (2004). Efficiency and financial performance changes of Malaysian banking institutions in merger and acquisition. Unpublished. $1-19$.

5. Fauzias, M.N. and Ruzita, A.R. (2003). Corporate restructuring and its wealth effects: the case of Malaysian Resources Corporation. Unpublished p. 1-46.

6. Fauzias, M.N. (1992). Corporate takeover and market efficiency: the Malaysian experience. Journal Pengurusan 11: 75 - 94.

$7 . \quad$ (1993). Acquisition announcement and stock price behaviour: the Malaysian experience. Journal Pengurusan 12: 85 - 109.

8. Houston, J.F, James, C.M., and Ryngaert, M.D. (2001). Where do merger gains come from? Bank merger from the perspective of the insiders and outsiders. Journal of Financial Economics 60: 285 - 331.

9. Houston, J.F. and Ryngaert, M.D. (1994). The overall gains from large bank mergers. Journal of Banking and Finance 18: $1155-1176$.

10. James, C. and Weir, P. (1987). Returns to acquirers and competition in the acquisition market: the case of banking. Journal of Political Economy 95: 355 - 370.

11. Jarrell, G.A., Brickley, J.A., and Netter, J.M. (1988). The market for corporate control: the empirical evidence since 1980. Journal of Economic Perspectives 2: 49 - 68.

12. Jensen, M. and Ruback, R.S. (1983). The market for corporate control. Journal of Financial Economics 11: $5-50$.

13. Kawai, Masahiro. The resolution of the East Asian crisis: financial and corporate sector restructuring, Journal of Asian Economics, volume 11, 2000, pp. 133-168.

14. Neely, E. (1987). Banking acquisitions: acquirer and target shareholder returns. Financial Management 16: $66-73$.

15. Ogden, J.P, Jen, F.C., and O’Connor, P. F. (2003). Advanced Corporate Finance Policies and Strategies. Prentice Hall, New Jersey.

16. Rhoades, S.A. (1998). The efficiency effects of bank mergers: an overview of case studies of nine mergers. Journal of Banking and Finance 22: 273 - 291.

17. Siegel, Jeremy J. Stocks for the Long Run. Third Edition, McGraw Hill, 2002. 